\title{
Knowledge Level of Pigeonpea Seed Growers about Improved Seed Production Technologies - A Critical Analysis
}

\author{
Y.D. Chithra ${ }^{*}$, S.K. Meti ${ }^{1}$, R.S. Bhawar ${ }^{2}$ and G.N. Maraddi ${ }^{1}$ \\ ${ }^{1}$ Department of Agricultural Extension Bangalore, University of Agricultural Sciences, \\ Bangalore-560065, Karnataka, India \\ ${ }^{2}$ Department of Dairy Economics, Statistics and Management division (DES\&M), ICAR- \\ National Dairy Research Institute, Karnal, 132001, India
}

*Corresponding author

\begin{abstract}
A B S T R A C T
Keywords

Pigeonpea, seed growers,

Knowledge level, Zero

order correlation,

Multiple regression

Article Info

Accepted:

08 August 2018

Available Online:

10 September 2018

Pigeonpea, as an important pulse crop, is an integral part of subsistence and sustainable production systems of Karnataka. A study was undertaken to assess the knowledge level of pigeonpea seed growers in Raichur district of Karnataka. Ex-post facto research design and purposive sampling technique is being used in the study. A total of 40 pigeonpea seed growers selected as a respondents for the study. The study revealed that more than two fifth $(42.50 \%)$ of seed growers fall under high knowledge category, followed by medium $(32.50 \%)$ and low knowledge $(25.00 \%)$. The variables like education, farming experience, achievement motivation, management orientation and mass media participation were showed significant relationship with knowledge level of pigeonpea growers at 5 per cent level of probability. The $\mathrm{R}^{2}(0.672)$ value indicated that, the twelve independent variables put together, contributed a significant amount of variation $(67.20 \%)$ in the overall knowledge level of pigeonpea seed growers.
\end{abstract}

\section{Introduction}

Legumes rank second in importance to cereals as human food sources because they contain protein almost comparable to what is derived from animal and fish meat. Legumes, regarded as poor man's meat, are the cheapest sources of protein among the underprivileged that cannot afford animal and fish proteins (Mula and Saxena 2010).

Pigeonpea (Cajanus cajan) is a leguminous crop which grows abundantly in many countries such as India, some regions of Africa, Central America, Australia and Asia. It continues to be an agricultural occupation sustained by small food producers in Trinidad and Tobago as well.

In Dominican Republic, pigeonpea is also grown on small farms of less than 2 hectares and about $80 \%$ of the annual harvest is exported, in the form of canned or frozen green peas (Diwedi et al., 2011). Pigeonpea is a nutritious food being rich in protein and well-known for its usefulness in increasing 
soil fertility, preventing soil erosion and in suppressing weeds in upland farms. It has a wide adaptability to different climates and soils. This crop can tolerate higher temperatures than other legume crops such as pigeonpea, lentils, and peas. It is cultivated to some extent in most tropical and subtropical environments. The exceptions are areas that are excessively wet or that experience severe frost. In terms of production, there is an increasing trend in pigeonpea cultivation globally with respect to area and production from 3.66 million hectares ( $\mathrm{M}$ ha) and 2.23 million tons (MT) in 1961 to $4.63 \mathrm{M}$ ha and 5.46 MT in 2015. However, the productivity level of pigeonpea has stagnated over time, estimated currently at $990 \mathrm{~kg}$ per hectare (Annon., 2015).

Seed production is rather a specialized type of crop growing, a thorough knowledge of a crop in respect of its growth habits, mode of pollination, proper isolation distance, etc., are of prime importance in the production of quality seed. The handling of the seed crop, its curing, threshing, cleaning, grading, packing and storage needs specialized knowledge. With recent technological development in agriculture, seed production has become more complex business and requires careful planning for successful operations. The seed production is systematically organized, carefully planned based on the best information available and aimed to achieve higher yield and best quality of seed out of their resources.

It is deliberate and conscious effort on the part of the seed grower to think about the seed programme in advance and adjust them according to new knowledge on technological development changes in physical and economic situation, price structures etc. knowledge has been found to be an important factor contribution to adoption of recommended technology by the farmers.
Keeping in this view, a study was undertaken to asses the knowledge level of pigeonpea seed growers about improved seed production technology and to know the relationship of knowledge level of pigeonpea seed growers with their independent variables.

\section{Materials and Methods}

The study was conducted in Raichur district of Karnataka. In Raichur district, Raichur taluk had maximum number of seed growers and hence selected purposively as a locale of the study. The villages having maximum number of farmers involved in seed production were listed in descending order in consultation with seed unit UAS Raichur. From the list, five villages namely, Idapnur, Marched, Gunjalli, Huda and gonal having maximum number of seed growers were selected. By using purposive sampling procedure 13 seed growers from Idapnur, 11 seed growers from Marched, 7 seed growers from Gunjalli, 5 seed growers from Huda and 4 seed growers from Gonal were selected thus, the total sample size constituted to 40 respondents. The data were collected with the help of a pre tested interview schedule through personal interview.

A teacher made test was developed by taking 6 dimensions and 22 statements were developed to measure the knowledge of farmers about the seed production practices. Six dimensions namely seeds and sowing, fertilizer application, weed management and inter cultivation, irrigation management, plant protection measures and seed production techniques were listed and the statements were framed carefully in consultation with the special officer (seeds) at seed unit UAS Raichur. A maximum score of 2 was given for the farmer who had full knowledge of the recommended practice pertaining to these dimensions. A score of 1 was assigned when the farmer expressed partial knowledge and a 
score of 0 was assigned when the farmer expressed total ignorance. Thus, the total knowledge score could range from 0 to 44 . The total score of knowledge for each respondent was computed by adding up the scores of twenty two statements. The knowledge level categories were formulated as low, medium and high on the basis of mean $\pm \mathrm{SD}$.

The correlation analysis was carried out to find out the relationship between personal, socio-economic variables with knowledge. To explain the contribution of selected factors on knowledge stepwise multiple regression analysis was carried out.

\section{Results and Discussion}

\section{Overall knowledge of pigeonpea seed} growers about seed production practices

It is evident from the Table 1 (Fig. 1) that the sample as a whole indicated that 42.50 per cent of growers belonged to high knowledge level category. Whereas, 32.50 per cent of the growers were in medium knowledge level category and 25.00 per cent of growers were in low knowledge level category. The findings were in conformity with the findings of Raghavendra (2010) and Teresa and Lirag (2016).

\section{Practice wise knowledge of pigeonpea seed} growers about seed production

An attempt was made to study the knowledge level of pigeonpea seed growers with respect to seed production practices, which is presented in the Table 2 (Fig. 2).

It is interesting to note that cent percent of the growers possessed full knowledge on varietal aspects, followed by spacing (80.00\%), suitability of soil (72.50\%) and seed rate $(50.00 \%)$. However, with regard to fertilizer application 62.50 per cent of the growers possessed full knowledge about FYM application. However, with regard to the application of chemical fertilizers and split dose of $\mathrm{N}$ application was known by 67.50 and 47.50 per cent of growers, respectively.

The weed management, a decidable factor on yield was known by considerable number of growers. The knowledge on hand weeding $(70.00 \%)$ and inter-cultivation practice $(65.00 \%)$ were known fully by the growers.

However, the knowledge on usage of weedicide was known fully by 45.00 per cent and at the same time partially by 50.00 per cent. Further, the nipping practice was not known by many of the seed growers and 45.00 per cent of them were exhibited partial knowledge. Similarly, 87.50 per cent of the growers had possessed full knowledge with respect to irrigation schedule and more over 45.00 per cent of them were not known the critical stages of irrigation, which is required during flowering and pod setting stage.

With regard to insect pest as well as disease management, the percentage ranging from 35.00 to 57.00 were possessed partial knowledge and in some cases like pod fly management, leaf webber management and leaf spot management more than 50 per cent were not known any technical knowledge in managing these menace.

It is interesting to note that except the grading of seeds which was expressed by 80.00 per cent of the growers not known the grading techniques. While the other seed production techniques like roughing, isolation distance, seed standard maintenance, seed processing and getting optimum yield were known by majority of the seed growers with varying percentage from 60.00 to 77.50. These findings are in line with the findings of Mula and Sexena (2010) and Raghavendra (2010). 
Relationship between socio economic characteristics of seed growers with their knowledge level

Zero order correlation between knowledge level of pigeonpea seed growers with their independent variables

The data in the Table 3 represents the relationship of independent variables with knowledge level of pigeonpea seed growers. The variables like education, farming experience, achievement motivation, management orientation and mass media participation were showed significant relationship with knowledge level at 5 per cent level of probability. Whereas, risk orientation and extension participation showed significant relationship with knowledge level at 1 per cent level of probability.

Other variables like age, annual income, size of land holding, cropping intensity and information seeking behaviour showed nonsignificant relationship with knowledge level of pigeonpea seed growers. The results are in conformity with Archana et al., (2014), Aregawi (2014), Aparan Jaiswal and Patel (2012), Shakya et al., (2008), Sabanna (2013), Kharatmol (2006) and Shailesh et al., (2013).

Table.1 Overall knowledge of pigeonpea seed growers about seed production practices

\begin{tabular}{|c|l|c|c|}
\hline \multicolumn{1}{|c|}{ Category } & Frequency & Percentage \\
\hline SI. No. & \multicolumn{1}{|c|}{$(\mathrm{n}=40)$} \\
\hline 1. & Low (Mean $-0.425 *$ SD) & 10 & 25.00 \\
\hline 2. & Medium (Mean $\pm 0.425 *$ SD) & 13 & 32.50 \\
\hline 3. & High (Mean+ $0.425 *$ SD) & 17 & 42.50 \\
\hline & Mean & \multicolumn{2}{|c|}{76.05} \\
\hline
\end{tabular}

Fig.1 Overall knowledge of pigeonpea seed growers about seed production practices

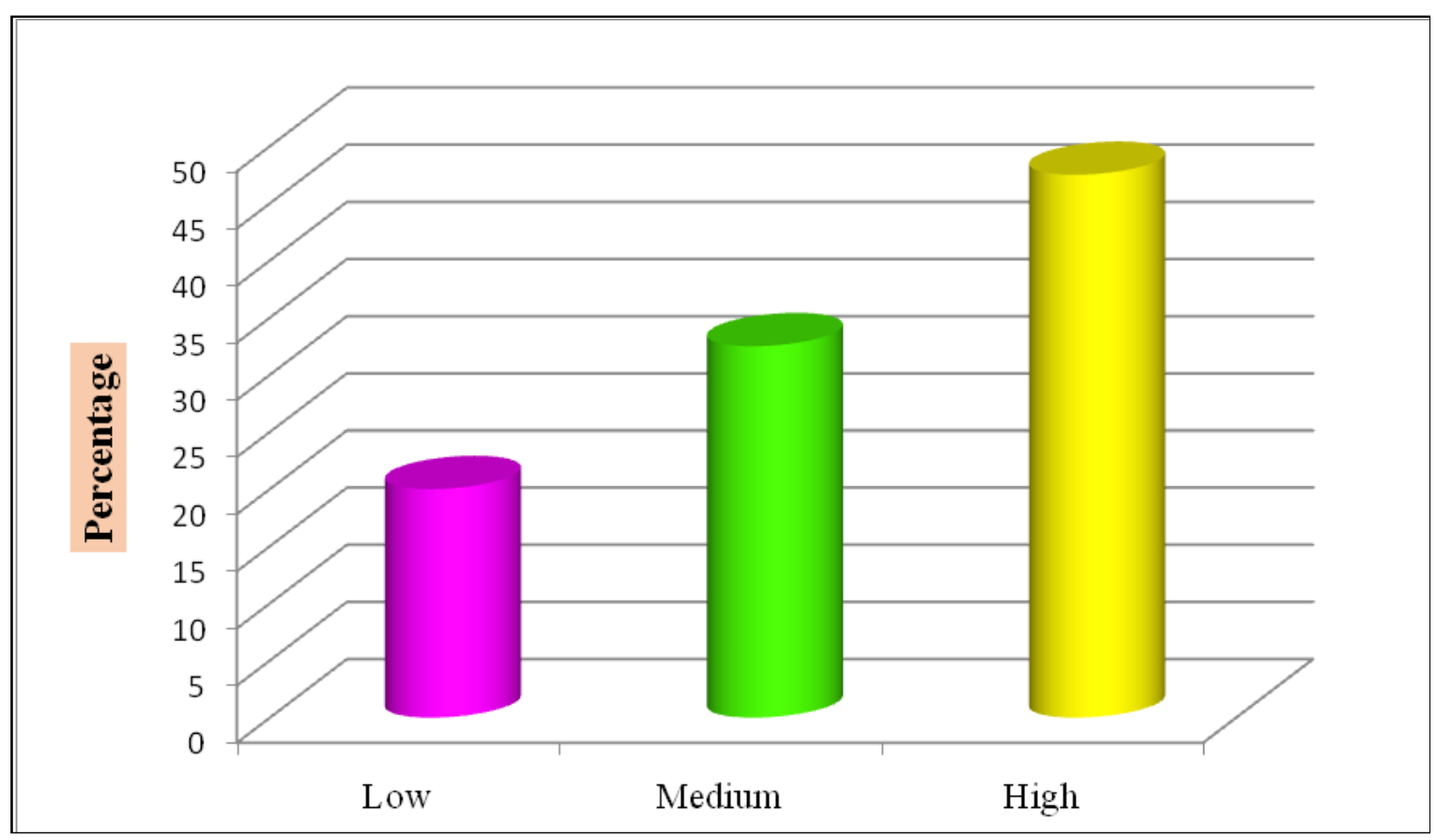


Fig.2 Practice wise knowledge of pigeonpea seed growers about seed production

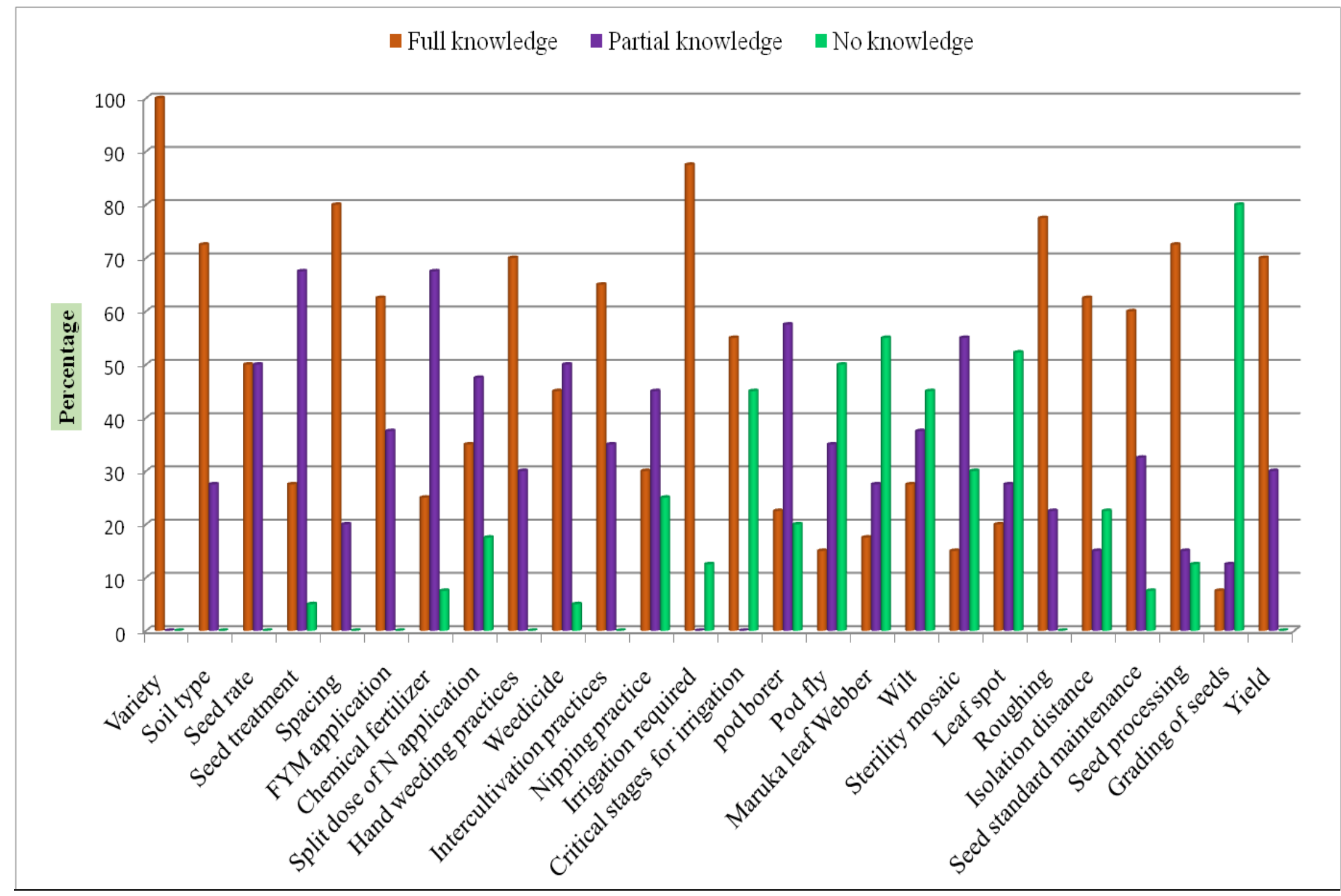


Table.2 Practice wise knowledge of pigeonpea seed growers about seed production

$(n=40)$

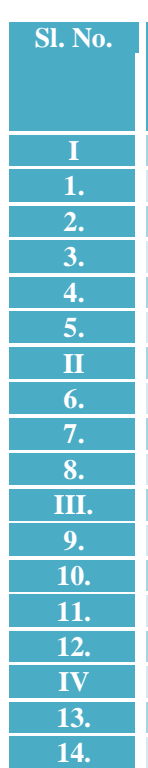

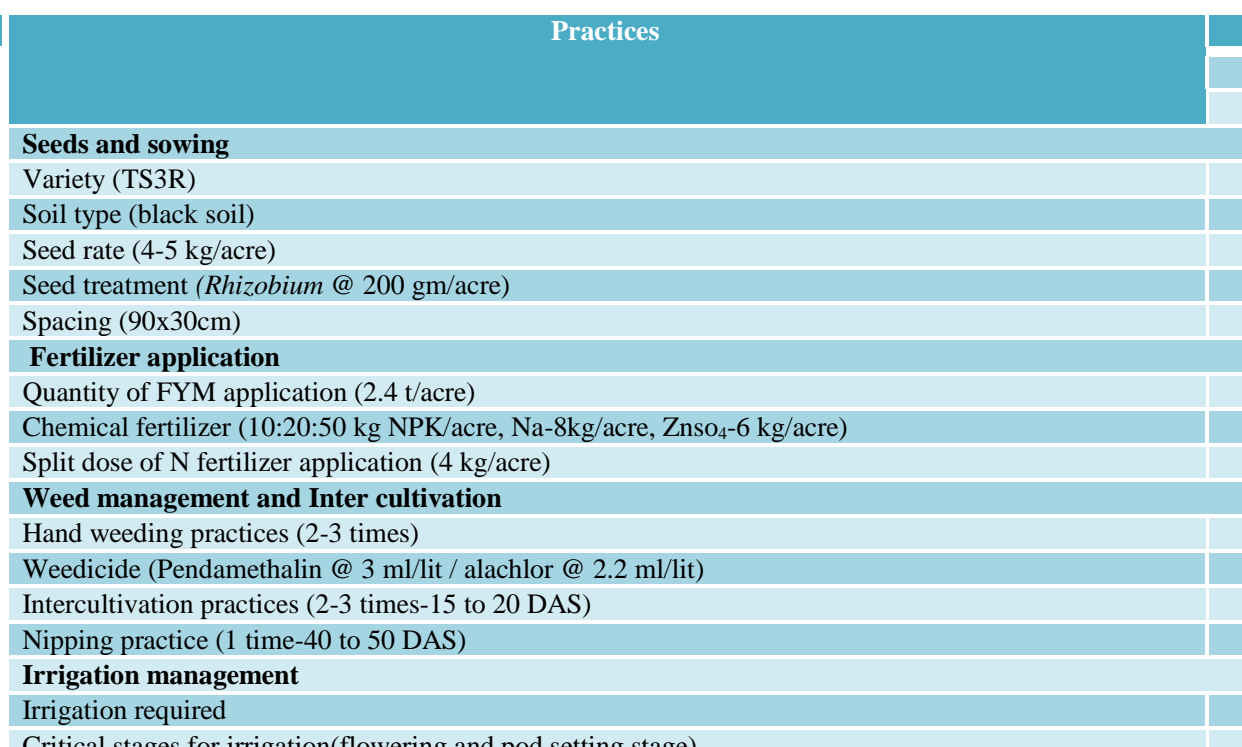

\begin{tabular}{|c|c|c|}
\hline \multicolumn{2}{|c|}{ FK } & \\
\hline $\mathbf{F}$ & $\%$ & $\mathbf{F}$ \\
\hline 40 & 100.00 & 0 \\
\hline 29 & 72.50 & 11 \\
\hline 20 & 50.00 & 20 \\
\hline 11 & 27.50 & 27 \\
\hline 32 & 80.00 & 8 \\
\hline
\end{tabular}

nowledge level

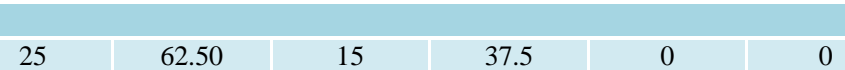

\begin{tabular}{|c|c|c|c|c|c|}
\hline 25 & 62.50 & 15 & 37.5 & 0 & 0 \\
\hline 10 & 25.00 & 27 & 67.50 & 3 & 7.50 \\
\hline 14 & 35.00 & 19 & 47.50 & 7 & 17.50 \\
\hline
\end{tabular}

35.00

19

47.50

\begin{tabular}{|c|c|c|c|c|c|}
\hline 28 & 70.00 & 12 & 30.00 & 0 & 0.00 \\
\hline 18 & 45.00 & 20 & 50.00 & 2 & 5.00 \\
\hline 26 & 65.00 & 14 & 35.00 & 0 & 0.00 \\
\hline 12 & 30.00 & 18 & 45.00 & 10 & 25.00 \\
\hline 35 & 87.50 & 0 & 0.00 & 5 & 12.50 \\
\hline 22 & 55.00 & 0 & 0.00 & 18 & 45.00 \\
\hline
\end{tabular}

Critical stages for irrigation(flowering and pod setting stage)

\section{Knowledge level}

Contd.....

\section{Plant protection measure \\ Insect pest management}

i) Pod borer (propanophos 50 EC @ $2 \mathrm{ml} / / \mathrm{lit}$ )

ii) Pod fly (methomil 40 SP @ 0.6 gm + Jaggary 10 gm/lit)

iii) Maruka leaf Webber (propanophos 50 EC @ 2ml/lit)

Disease management

i) Wilt (Seed treatment with trichoderma @ $4 \mathrm{~g} / \mathrm{kg} / \mathrm{capton} 80 \mathrm{WP} @ 2 \mathrm{~g} / \mathrm{kg}$ )

ii) Sterility mosaic (Dicofol $18.5 \mathrm{EC} @ 2.5 \mathrm{ml} / \mathrm{lit}$ )

iii) Leaf spot (Seed treatment with capton $80 \mathrm{WP} @ 2 \mathrm{~g} / \mathrm{kg} / \mathrm{acre})$

Seed production techniques

Roughing (2 times-before flowering and after flowering)

Isolation distance (foundation seed-250 m, certified seed-100 m)

Seed standard maintenance (Germination percentage $-75 \%$, Seed moisture content- $9 \%$, physical purity- 98\%)

Seed processing

Grading of seeds

F

FK

$\%$

F PK

$\%$

NK

\begin{tabular}{|c|c|c|c|c|c|}
\hline 9 & 22.50 & 23 & 57.50 & 8 & 20.00 \\
\hline 6 & 15.00 & 14 & 35.00 & 20 & 50.00 \\
\hline 7 & 17.50 & 11 & 27.50 & 22 & 55.00 \\
\hline 7 & 27.50 & 15 & 37.50 & 18 & 45.00 \\
\hline 6 & 15.00 & 22 & 55.00 & 12 & 30.00 \\
\hline 8 & 20.00 & 11 & 27.50 & 21 & 52.25 \\
\hline
\end{tabular}

FK = Full Knowledge, PK = Partial Knowledge, NK = No Knowledge, F = Frequency, \% = Percentage 
Table.3 Zero order correlation between knowledge level of pigeonpea seed growers with their independent variables

\begin{tabular}{|c|c|c|}
\hline SI. No. & Independent variables & Knowledge level (r value) \\
\hline 1. & Age & $0.046^{\mathrm{NS}}$ \\
\hline 2. & Education & $0.239 *$ \\
\hline 3. & Size of land holding & $0.054^{\mathrm{NS}}$ \\
\hline 4. & Farming experience & $0.149 *$ \\
\hline 5. & Annual income & $0.048^{\mathrm{NS}}$ \\
\hline 5. & Risk orientation & $0.330 * *$ \\
\hline 6. & Achievement motivation & $0.173 *$ \\
\hline 7. & Management orientation & $0.221 *$ \\
\hline 8. & Cropping intensity & $0.099^{\mathrm{NS}}$ \\
\hline 9. & Mass media participation & $0.268 *$ \\
\hline 10. & Extension participation & $0.318 * *$ \\
\hline 11. & Information seeking behaviour & $0.005^{\mathrm{NS}}$ \\
\hline
\end{tabular}

NS - Non-significant; $r=$ Correlation co-efficient,

$*$ Significant at $5 \%, \quad * *$ Significant at $1 \%$

Table.4 Step-wise regression analysis of the independent variables of pigeonpea seed growers with their knowledge level

\begin{tabular}{|c|l|c|c|c|}
\hline S. No. & \multicolumn{1}{|c|}{ Independent variables } & Regression coefficient (B) & $\begin{array}{c}\text { Standard } \\
\text { error }\end{array}$ & ' $t^{\text {' values }}$ \\
\hline 1. & Age & 0.157 & 0.197 & $0.793^{\text {NS }}$ \\
\hline 2. & Education & 1.396 & 0.754 & $1.856^{*}$ \\
\hline 3. & Size of land holding & 0.036 & 0.114 & $0.318^{\text {NS }}$ \\
\hline 4. & Farming experience & 1.043 & 0.267 & $1.161^{*}$ \\
\hline 5. & Annual income & 0.056 & 0.546 & $0.214^{\text {NS }}$ \\
\hline 5. & Risk orientation & 1.118 & 1.064 & $1.511^{* *}$ \\
\hline 6. & Achievement motivation & 1.439 & 0.804 & $1.346^{*}$ \\
\hline 7. & Management orientation & 1.873 & 1.457 & $1.399^{*}$ \\
\hline 8. & Cropping intensity & 0.091 & 0.440 & $0.061^{\mathrm{NS}}$ \\
\hline 9. & Mass media participation & 1.325 & 0.295 & $1.100^{*}$ \\
\hline 10. & Extension participation & 1.139 & 0.285 & $1.490^{* *}$ \\
\hline 11. & Information seeking behaviour & 1.060 & 0.242 & $0.247^{\text {NS }}$ \\
\hline
\end{tabular}

$\mathrm{R}^{2}: 0.672 ; * *$ : Significant at 0.01 probability level, *: Significance at 0.05 probability level

Step wise regression analysis of the different independent variables of pigeonpea seed growers with their knowledge level

It is apparent from value coefficient of multiple regression $R^{2}(0.672)$ given in Table
4 that, the twelve independent variables put together, contributed a significant amount of variation $(67.20 \%)$ in the overall knowledge level of the growers. Further it is also indicated by the table that, the independent variables like, education, farming experience, achievement motivation, management 
orientation and mass media participation were significant at 5 per cent level of probability. Whereas, risk orientation and extension participation were significant at 1 per cent probability level. It signifies that these independent variables are important predictors of knowledge level of pigeonpea seed growers. The results are in partial conformity with the findings of Sarmah and Singh (2006).

The study revealed that the pigeonpea growers had high knowledge about spacing, suitability of soil, seed rate and fertilizer application. While, majority of them had knowledge about critical stage of irrigation, variety, soil type and sowing time. The study also revealed that majority of the respondents had partial knowledge regarding weedicide application and management of wilt. Most of the seed growers had poor knowledge about roughing, seed standard maintenance, isolation distance and seed processing. Correlation analysis indicated that all the socio-economic, communication and psychological factors had significant positive relationship with knowledge level of pigeonpea seed growers except age, annual income, size of land holding, cropping intensity and information seeking behaviour.

The study pointed out that education, farming experience, risk orientation, achievement motivation, management orientation, mass media participation and extension participation were the important factors which had direct and indirect effect on knowledge of pigeonpea seed growers. Hence, the government and private organization should emphasis for up scaling these variables for their advantage in order to improve knowledge level of pigeonpea seed growers and also intensive training programs needs to be conducted by government and nongovernment agencies regarding isolation distance and seed standard maintenance in order improve the knowledge level of pigeonpea seed growers.

\section{Acknowledgement}

I recall the words of Henry Adams who said "A teacher effects eternity, he can never tell when his influence stops". I am overwhelmed with heartfelt feelings of gratitude and profound indebtedness to my beloved teacher Dr. S. K. METI, Dean (Agri), AC, Raichur and Director of Extension, Department of Agricultural Extension Education, University of Agricultural Sciences, Raichur and Chairman of my Advisory Committee, for his inspiring guidance, subtle and expert help, sustained interest in planning and execution during my research period. I sincerely confess that it would have been a daydream on my part to accomplish this present investigation without the involvement of this ever helpful personality. I feel immense pleasure in expressing my deep sense of gratitude, esteem and sincere feelings of indebtedness to members of my Advisory Committee, Shri. J. TULASIRAM, Associate Professor, Department of Agricultural Extension, Dr. G. N. MARADDI, Assistant Professor, Department of Agricultural Extension and Dr. SANGEETHA I. MACHA, Assistant Professor, Department of Seed Science and Technology, University of Agricultural Sciences, Raichur. I also acknowledge my respondents who has given me data for my Research.

\section{Abbreviations}

SD: Standard Deviation

\section{Competing Interests}

There is no competing interest exists

\section{Authors Contribution}

Y. D. Chithra designed the study, performed the statistical analysis, wrote the protocol, and 
wrote the first draft of the manuscript.

S. K. Meti guided and approved the manuscript

\section{References}

Anonymous, 2015, Agricultural Statistics at a Glance, Directorate of Economics and Statistics, Ministry of Agriculture, Government of India.

Aparna Jaiswal and Patel, M. M., 2012, Entrepreneurial behaviour of rural women. Indian Res. J. Extn. Edu., 12(1): 21-26.

Archana, K. N., Natikar, K. V. and Joshi, S. S., 2014, Entrepreneurial behaviour of commercial seed growers and other farmers. Karnataka. J. Agric. Sci., 27(4): (548-550).

Aregawi, L.M., 2014 Entrepreneurial behaviour of seed growers in Ethiopia.

J. Development and Agric. Econ., 3(6), 436-412.

Dwivedi, A.P., Singh, S. R. K., Mishra Anupam, Singh, R.P., Singh Mamta. 2011, Adoption of improved technology of pigeonpea. $J$. of Community Mobilization and Sustainable Dvpt. 6(2):150-154.

Kharatmol, 2006, Impact of trainings conducted on vermicompost by Krishi Vigyan Kendra, Bijapur. $M$. Sc. (Agri.) Thesis, Univ. Agric. Sci., Dharwad (India).

Mula M. G and Saxena K. B. 2010, Lifting the level of awareness on pigeonpea A global perspective. Patancheru 502
324, Andhra Pradesh, India: International Crops Research Institute for the Semi-Arid Tropics. 540. ISBN: 978-92-9066-535-9.

Raghavendra, K. M., 2010, An impact study on farmers knowledge and adoption level of sunflower demonstration farmers in Bijapur district of Karnataka. M. Sc. (Agri.) Thesis, Univ. Agric. Sci., Dharwad (India).

Sabanna, K. M., 2013, A study on sunflower production technologies - constraints analysis in Raichur district of Karnataka. M. Sc. (Agri.) Thesis, Univ. Agric. Sci., Raichur (India).

Sarmah, R. C. and Singh, A. K., 2006, Determinants of entrepreneurship in Agriculture. Agriculture Extn. Review, 35(3): 538-539.

Shailesh kumar, Gyanendra and Yadav K. V., 2013, Factors influencing entrepreneurial behaviour of vegetable growers. Indian Res. J. Extn. Edu., 13(1).

Shakya, M. S., Patel, M. M. and Singh, V. B., 2008, Knowledge level of Pigeonpea growers about Pigeonpea production technology. Indian Res. J. Extn. Edu., $8(2)$.

Teresa and Lirag, 2016, Farmers' Knowledge and Awareness on Pigeonpea (Cajanus cajan) in Camarines Sur, Philippines Journal of Agriculture and Ecology Research International 9(2): 1-10, 23941073

\section{How to cite this article:}

Chithra, Y.D., S.K. Meti, R.S. Bhawar and Maraddi, G.N. 2018. Knowledge Level of Pigeonpea Seed Growers about Improved Seed Production Technologies - A Critical Analysis. Int.J.Curr.Microbiol.App.Sci. 7(09): 876-884. doi: https://doi.org/10.20546/ijcmas.2018.709.105 